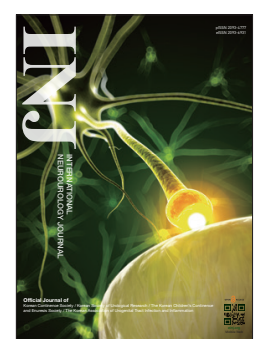

\title{
Laparoscopic Approach for Intravesical Surgery Using Pneumovesicum in Urology: Literature Review
}

\author{
Bum Sik Tae, Hoon Choi, Jae Young Park, Jae Hyun Bae \\ Department of Urology, Korea University Ansan Hospital, Korea University College of Medicine, Ansan, Korea
}

Minimally invasive laparoscopic surgical procedures are increasingly being used in the management of various urological diseases. In particular, the laparoscopic approach for intravesical surgery using pneumovesicum (LPV) is a minimally invasive alternative with potential advantages including decreased morbidity, shorter hospital stays, and improved cosmesis. We review the applications of LPV in urology, summarize data for different surgical approaches, and provide an overview of patient management, as well as other considerations. This narrative review focused primarily on articles indexed in PubMed, Google Scholar, Scopus, and Embase databases. No formal search strategy was used, and no meta-analysis of data was performed.

Keywords: Laparoscopy; Urology; Pneumovesicum; Transvesicoscopy

- Conflict of Interest: JYP, a member of the Editorial Board of INJ, is the third author of this article. However, he played no role whatsoever in the editorial evaluation of this article or the decision to publish it. No potential conflict of interest relevant to this article was reported. No potential conflict of interest relevant to this article was reported.

\section{INTRODUCTION}

The development of the laparoscopy instrument has enabled various surgical methods. For instance, the laparoscopic approach for intravesical surgery using pneumovesicum (LPV) has transformed the concept of infusing the bladder with gas instead of water. This concept, also known as pneumovesicum, was initially described 50 years ago. [1] Since then however, pneumovesicum has not been widely used for cystoscopy or cystometry. However, this procedure has recently received attention because of its application to transvesical laparoscopy. The LPV was initially described by Yeung et al. [2] during laparoscopic ureteroneocystostomy. To our knowledge, the term is not clearly defined and is sometimes referred to as a combination of LPV, pneumovesicoscopic, or transvesicoscopic approaches.
LPV is very helpful in overcoming challenging surgical procedures. In addition, many studies have shown that LPV has potential benefits over traditional techniques, including improving cosmesis, reducing postoperative pain and postoperative ileus, fewer wound complications, and shorter hospital stays [2-7]. It can also overcome many complications that may occur in transperitoneal laparoscopy. First, because $\mathrm{CO}_{2}$ insufflation is limited to the bladder, the intraabdominal pressure is not sufficiently excessive to cause oliguria. Second, $\mathrm{CO}_{2}$ pneumovesicum does not appear to affect the renal arterial or venous flow, nor does it introduce a $\mathrm{CO}_{2}$ embolism [8].

However, LPV has not been used to treat several diseases because it requires a small working space. In addition, some procedures are technically demanding, even for an experienced laparoscopic surgeon $[9,10]$. Nevertheless, studies on LPV have
Corresponding author: Jae Hyun Bae (iD http://orcid.org/0000-0001-9862-3545 Department of Urology, Korea University Ansan Hospital, Korea University College of Medicine, 123 Jeokgeum-ro, Danwon-gu, Ansan 15355, Korea E-mail: urobae@genetherapy.or.kr / Tel: +82-31-412-5190 / Fax: +82-31-412-5194 Submitted: January 5, 2018 / Accepted after revision: January 19, 2018
This is an Open Access article distributed under the terms of the Creative Commons Attribution Non-Commercial License (http://creativecommons.org/licenses/by-nc/4.0/) which permits unrestricted non-commercial use, distribution, and reproduction in any medium, provided the original work is properly cited. 
demonstrated excellent results, and it has been employed in various aspects of urological diseases beyond vesicoureteral reflux (VUR) management. Herein, we review the application of LPV in urology, summarize data of different surgical approaches, and provide an overview of patient management, as well as other considerations.

\section{MATERIALS AND METHODS}

We performed a narrative review of relevant research. While no formal search strategy was employed, the following search terms were primarily used to identify relevant sources: transvesicoscopy, pneumovesicum, pneumovesicoscopic, transvesical laparoscopy, and pneumovesical laparoscopy. PubMed, Scopus, and Embase were searched to identify potentially relevant published literature. The search was performed in November 2017. References from relevant sources were examined to identify additional sources for this review. A synopsis of relevant references was created.

\section{RESULTS}

\section{Overview of Included Studies}

Total 52 studies about LPV published between 2005 and 2017 were reviewed. Ureteral reimplantation were described in 18 studies, management mesh complication in 6 studies, management of vesico-vaginal fistula (VVF) in one study, removal of bladder foreign body in 9 studies, management of benign prostate hyperplasia (BPH) in 5 studies, management of prostate cancer in 2 studies, management of distal ureter and bladder cuffing in nephroureterectomy in 7 studies and bladder diverticulectomy in 4 studies.

\section{Port Placement, Pneumovesicum Establishment, and Complications}

The bladder should be distended with saline under cystoscopy to establish pneumovesicum [2]. The laparoscopic port is then inserted under a cystoscopy guide, and the bladder is inflated with $\mathrm{CO}_{2}$ while draining the saline. Although the number of ports depends on the procedure, most require three for suturing. Two 3or 5-mm trocars are used for the working ports, and a 5-mm trocar for the midline camera port that houses a $0^{\circ} 5$-mm telescope [11]. However, transvesical laparoendoscopic single-site surgery (T-LESS) can be performed in patients who do not need delicate suturing or adults who have a relatively large working space [12-14]. When suturing is needed, a $1.5-\mathrm{cm}$ longitudinal skin incision is made $2 \mathrm{~cm}$ above the pubic symphysis, and the inner ring of a TriPort access system is inserted directly into the bladder via a skin incision under cystoscopic control.

The main reason for open conversion in LPV surgery is port displacement. A related study on ureteral implantation using LPV showed an open conversion rate of approximately 5\%$10 \%$, predominantly due to port displacement [15]. To overcome this limitation, some researchers have suggested that 5-mm locking trocars (Pediport, Covidien, Dublin, Ireland) or self-retaining trocars with an umbrella (Pediport Ref 240 ST diameter $5.5 \mathrm{~mm}$, Covidien) could reduce port displacement rate without significantly depending on cystopexy $[5,6]$. However, open conversion can occur even if port access is difficult or pneumovesicum (PV) is not maintained. Valla et al. [6] reported that $6 \%$ of patients in their case series were converted to an open approach, because of the difficulty of port access to the bladder. In particular, increased elasticity and mobility of the bladder in patients younger than 2 years lead to more difficult PV maintenance.

Common complications related to port insertion include intraperitoneal urine leakage and emphysema. Most emphysemarelated PVs are resolved with conservative management. However, intraperitoneal urine leakage requires prolonged urethral catheterization. Urinary leakage should be considered after catheter removal when abdominal distention is noted, especially in cases of oliguria and adequate hydration [11]. Kutikov et al. [11] observed that all the leaks at port sites were intraperitoneal, and that all patients needed urethral catheterization. Ports may traverse the peritoneum and induce gas leakage into the peritoneal cavity if the port was placed too cephalad. Pneumoperitoneum can lead to collapsed bladders, poor visibility, and emphysema. Jayanthi and Patel [16] reported that transumbilical Veress needle placement vent $\mathrm{CO}_{2}$ and allow the bladder to distend appropriately.

Kilincaslan et al. [17] reported that long-term PV or excessive $\mathrm{CO}_{2}$ pressure in the bladder can cause upper tract injury. In their experimental VUR model, they found that the intraipsilateral upper urinary tract and the contralateral renal medulla had significant histopathological changes upon intrauterine $\mathrm{CO}_{2}$ insufflation. However, Xiang et al. [8] demonstrated that $\mathrm{CO}_{2}$ pneumovesicum at a pressure of $10 \mathrm{mmHg}$ for 2 hours did not result in any demonstrable deleterious effect in their pig model. In addition, $\mathrm{CO}_{2}$ was mildly acidic (carbonic acid) and $\mathrm{CO}_{2}$ pneumovesicum may have irritated the mucosal wall of the bladder. 
Therefore, it could feasibly affect bladder overactivity. However, few studies have evaluated the impact of $\mathrm{CO}_{2}$ pneumovesicum on the urinary tract and bladder function in humans.

\section{Ureteral Reimplantation With LPV Cohen technique}

Minimally invasive surgical procedures using laparoscopic techniques have been shown to be effective in managing patients with VUR. Since Lakshmanan et al. first reported laparoscopic extravesical reimplantation, various types of laparoscopic ureteral reimplantation techniques have been developed in this patient population [18]. The concept of transvesical laparoscopy surgery was first introduced in 2001 by Gill et al. [19] in a laparoscopic cross-trigonal ureteral reimplantation. Yeung et al. [2] were the first to report the cross-trigonal ureteral reimplantation technique under LPV with the bladder filled with $\mathrm{CO}_{2}$. This method demonstrated better success rates than the open cross-trigonal reimplantation. Current techniques have been shown to be safe, with a low complication rate and excellent success rates (92\%-98\%) (Table 1) [2,5-7,9,10,19-21].

Most operative techniques are similar to those described by Yeung et al. [2] and Valla et al. [6]. The procedure is mostly per- formed in the supine or lithotomy position, using three laparoscopic ports [2]. Intravesical mobilization of the ureter, dissection of the submucosal tunnel, and a Cohen type of ureteral reimplantation were performed under endoscopic guidance, similar to the open procedure. Generally, ureter mobilization is advanced for 2.5 to $3 \mathrm{~cm}$ into the extravesical space. The muscular defect in the ureteral hiatus was repaired with two or three 5-0 absorbable interrupted sutures to reduce air leakage in the perivesical space [2,6,21]. Maryland graspers, L-hooks, or endoscopic scissors facilitate the creation of a transverse submucosal tunnel. Resection or spatulation of the terminal part of the ureter or leaving the mucosal collar depends on the surgeon's preference [6]. In addition, ureteral stents or feeding tubes are not routinely used, but they may be considered in some patients undergoing bilateral ureteral reimplantation or those with megaureters requiring tapering ureteroplasty $[2,15]$.

Compared with open surgery, the benefits of LPV ureteric reimplantation include reduced bladder trauma and improved cosmesis. Valla et al. [6] demonstrated that the absence of wide cystotomy, the presence of gauze in contact with bladder mucosa, intravesical retraction, and minimal manipulation of the tissue around the trigone lead to decreased bladder trauma. In

Table 1. Published articles on pneumovesical laparoscopic ureteral reimplantation for management of vesicoureteral reflux

\begin{tabular}{|c|c|c|c|c|c|c|c|c|c|c|}
\hline Study ${ }^{a}$ & $\begin{array}{l}\text { Reported } \\
\text { year }\end{array}$ & $\begin{array}{l}\text { Case } \\
\text { No. }\end{array}$ & $\begin{array}{l}\text { Age }^{\mathrm{b})} \\
(\mathrm{yr})\end{array}$ & $\begin{array}{l}\text { Operative time } e^{\mathrm{b})} \\
(\mathrm{min})\end{array}$ & $\begin{array}{c}\text { Urethral } \\
\text { catheter } \\
\text { indwelling } \\
\text { (day) }\end{array}$ & $\begin{array}{l}\text { Hospital } \\
\text { stay }^{\text {b) }} \\
\text { (day) }\end{array}$ & $\begin{array}{l}\text { Follow- } \\
\text { up }^{\text {b) }} \\
(\mathrm{mo})\end{array}$ & $\begin{array}{c}\text { Perioperative } \\
\text { complication } \\
(\%)\end{array}$ & $\begin{array}{c}\text { Open } \\
\text { conversion } \\
(\%)\end{array}$ & $\begin{array}{l}\text { Success } \\
\text { rate } \\
(\%)\end{array}$ \\
\hline \multicolumn{11}{|c|}{ Politano-Leadbetter technique } \\
\hline Choi [4] & 2015 & 10 & 6.9 & Uni, 93; Bi, 133 & 5.1 & 6.2 & 9.0 & 0 & 0 & 100 \\
\hline Soh [7] & 2015 & 12 & 9.0 & Uni, 88; Bi, 324 & 2.3 & 3.7 & 47.3 & 8.3 & 0 & 94.4 \\
\hline \multicolumn{11}{|l|}{ Cohen technique } \\
\hline Yeung [2] & 2005 & 16 & 4.1 & Uni, 112; Bi, 178 & 1.0 & 1.9 & 27.6 & 0 & 6.2 & 96.0 \\
\hline Steyaert [9] & 2005 & 50 & 4.2 & N/A & 3.0 & N/A & N/A & 18.0 & 12.0 & 97.5 \\
\hline Kutikov [11] & 2006 & 27 & 5.0 & $\mathrm{Bi}, 138$ & N/A & 1.9 & N/A & 11.1 & 0 & 92.6 \\
\hline Canon [24] & 2007 & 52 & 5.7 & 199 & N/A & 2.1 & 11.0 & 6.0 & 2.5 & 91.0 \\
\hline Chung [3] & 2008 & 9 & 7.2 & 214.8 & 2.0 & 9.3 & N/A & 0 & 22.2 & 95.0 \\
\hline Valla [6] & 2008 & 72 & 4.2 & Uni, 82; Bi, 113 & 2.0 & 2.8 & 24.0 & 0 & 5.6 & 92.0 \\
\hline Jayanthi [16] & 2008 & 103 & N/A & $\mathrm{N} / \mathrm{A}$ & 1.5 & N/A & N/A & 2.0 & 2.9 & 94.0 \\
\hline Kawauchi [77] & 2009 & 30 & 14.5 & Uni, $145 ; \mathrm{Bi}, 230$ & $2-3^{c)}$ & 3.0 & N/A & N/A & 0 & 96.0 \\
\hline Marte [5] & 2010 & 14 & 13.6 & Uni, 112; Bi, 178 & 3.0 & 3.0 & 12.0 & 14.2 & 0 & 94.7 \\
\hline Abraham [78] & 2011 & 19 & 2.2 & 210 & 3.0 & 3.0 & 20.9 & 0 & 10.5 & 93.3 \\
\hline Hong [10] & 2011 & 28 & 6.0 & Uni, 166; Bi, 189 & 1.4 & 1.4 & 8.6 & 3.6 & 7.1 & 94.6 \\
\hline Emir [21] & 2012 & 11 & 6.9 & Uni, 217; Bi, 306 & 3.0 & 3.8 & 54.0 & 9.0 & 0 & 91.0 \\
\hline Chung [79] & 2012 & 48 & 3.7 & 155.6 & 1.6 & 1.6 & 16.3 & 0 & 6.2 & 96.4 \\
\hline Soh [7] & 2015 & 12 & 15.0 & Uni, 235; Bi, 268 & 2.4 & 3.4 & 39.2 & 0 & 0 & 94.7 \\
\hline Ansari [15] & 2017 & 17 & 4.6 & $\mathrm{Bi}, 135$ & 1.2 & 4.0 & 24.0 & 2.0 & 5.9 & 94.1 \\
\hline
\end{tabular}

Bi, bilateral; Uni, unilateral; N/A, not applicable.

${ }^{a)}$ First author [reference number]. ${ }^{\text {b) }}$ Mean. ${ }^{\text {c) }}$ Range. 
addition, the current approach reduces hospital stay, provides less postoperative discomfort, and reduces the cost of hospital stay, compared with the open approach $[3,10]$.

However, there is a learning curve because of the small working space within the bladder, and intravesical laparoscopic freehand suturing is needed. Steyaert and Valla [9] reported that all six conversions in their cohort occurred in the first series of 20 cases. Hong et al. [10] also reported that the mean operative time significantly decreased for the last 13 patients, compared with the first 13 (140 minutes vs. 220 minutes). The mean postoperative hospital stay was also significantly shorter for the last 13 patients than that for the first 13 (1.08 days vs. 1.69 days) [10]. In addition, the smaller the bladder, the smaller the working space. Hence, Kutikov et al. [11] and Valla et al. [6] suggested that the current method does not seem applicable to children younger than 6 months of age and a calculated cystographic bladder capacity of $130 \mathrm{~mL}$ could be considered the limit.

\section{Politano-Leadbetter technique}

Although the LPV ureteric reimplantation using the Cohen procedure has many advantages, the Cohen procedure has the distinct disadvantage of making future transurethral endourological cannulation and stone operation practically impossible [22]. To overcome this limitation, physicians in our center first described the Politano-Leadbetter technique with LPV [23]. However, few studies have been published on clinical results of the Politano-Leadbetter technique with LPV (Table 1) [4,7].

Port placement and creating the pneumovesical space are similar to those in the LPV Cohen technique. However, the location of the neo hiatus is different, because it is located along a straight line, superior to the original orifice [23]. The method of creating the submucosal tunnel and neo hiatus differs based on the surgeon's preference. Our center used a Diamond-Flex (Snowden-Pencer, CareFusion, Waukegan, IL, USA) to create the submucosal tunnel in our first experience report [23]. However, Soh et al. [7] inserted the cystoscope through the neo hiatus and dissected the ureter under cystoscopic visualization. Recently, our center presented a modified method of creating a submucosal tunnel and neo hiatus. After ureteral retraction under the submucosal tunnel from the neo hiatus, lifting the ureter exposes the posterior side of the bladder. In addition, muscle fibers are incised using hook electrocautery until the ureter can freely move from the base of the new hiatus [4].

Soh et al. [7] compared the results between LPV ureteral re- implantation Politano-Leadbetter and Cohen techniques. They reported that the operative time was slightly longer in the Politano-Leadbetter technique than that in the Cohen technique. However, no difference was found in the duration of hospital stay or success rate. However, our center reported an average of 92.5 minutes for unilateral and 150 minutes for bilateral reimplantation, which is comparable to that obtained in a previous study on the Cohen technique (Table 1) [4].

The LPV Politano-Leadbetter technique has important advantages over the Cohen technique. Soh et al. [7] reported that the tunnel length can be increased by advancing the ureter orifice to make a new one in various physiological positions by incising rather than tunneling into more distal epithelium and closing it over the ureter. In addition, a long tunnel can be created using the LPV Politano-Leadbetter technique, which is more effective in higher grades of reflux and orthotopic ureteral location after surgery [4]. Above all, the LPV Politano-Leadbetter has the potential advantage of allowing future transurethral endourological procedure, while a stone surgery practically impossible with the Cohen procedure [6,24].

\section{Megaureter or ureteral stricture}

Kutikov et al. [11] first reported short-term outcomes of GlennAnderson reimplantation using LPV for megaureter management or ureteral stricture in 2006 . However, the operative success rate was $80 \%$ for primary obstructed megaureter, and 2 of 5 patients experienced urine leakage. In a case series of 63 patients, Liu et al. [25] reported that the modified LPV GlennAnderson procedure was feasible and effective with minimal morbidity. They emphasized 2 major modifications to the traditional procedure. First, the bladder wall was incised superior laterally to move the hiatus proximally along the course of the ureter, and the detrusor muscle was sutured to the seromuscular layer of the ureter. Second, the mucosal groove rather than the tunnel was used to advance from the ureteral hiatus to the neck of the bladder. In their case series, $90 \%$ of the ureters were considered cured, and 10\% improved.

Kim et al. [26] reported successful results for laparoscopic intravesical detrusorrhaphy with ureteral plication of the megaureter. The most prominent aspect of their surgery was the plication of the ureter. After ureteral mobilization and resection of the distal portion, they inserted a $6 \mathrm{~F}$ Foley catheter into the megaureter to maintain tension during plication. They reported a mean operative time of 214 minutes including preoperative evaluation and successful surgical outcomes, improvement of 
obstruction, reduction of ureteral caliber, and absence of VUR while maintaining an orthotopic ureteral position [26]. However, tailoring of the ureter usually demands more time than simple reimplantation. Furthermore, caution should be exercised when considering Glenn-Anderson procedure in children younger than 6 months of age with small bladder capacity [11]. In addition, studies on the current approach are limited, and long-term follow-up data are lacking.

\section{Management of Intravesical Mesh Erosion With LPV}

Perforation of the bladder and urethra or erosion of the midurethral tape mesh after anti-incontinence surgery or cystocele repair surgery is not uncommon, and has potentially serious complications. These complications are associated with synthetic material mesh, and their incidence ranges from $0.07 \%$ to $1.5 \%[27,28]$. Surgical management is a priority because most of the bladder exposed meshes induce bladder stone formation or voiding symptoms. Traditionally, the transurethral or transvaginal approach has been used when mesh erosion is small. However, if it is not properly managed, vesicovaginal or urethrovaginal fistulas may develop [29,30]. The open approach has been used when mesh erosion is large or the bladder is perforated. However, obtaining the visual field is difficult if the mesh erosion is close to the ureteral orifice or near the bladder neck, even if the open approach is used.

However, LPV can be applied to manage patients with mesh erosion and it has excellent visualization and surgical outcomes. Al-Badr and Fouda [31] were the first to report successful outcomes for tension-free vaginal tape erosion management using LPV, but they only performed excision of the tape. Ingber et al. [32] then reported successful clinical results for single-port LPV mesh removal and reconstruction surgery. This approach has been reported to be very useful with advantages such as excellent visualization of the material when the mesh is in the anterior bladder neck [33]. In addition, Roslan and Markuszewski [34] reported that the operative time (mean, 59 minutes) and the length of hospital stay (mean, 2.4 days) were feasible with the current approach in a study of 9 patients with bladder mesh erosion (Table 2).

Compared with the transurethral approach, the current approach enables reconstruction using suturing not only by removing the erosion tape. This reconstruction technique leads to a faster recovery of the patient's symptoms than did the transurethral approach. Kim et al. [33] reported that reconstruction with suturing improved symptoms within 7 days in most patients, whereas patients with the transurethral technique had a symptom recovery period of 1 month in a previous case series. In addition, they demonstrated that closure of the mucosal and

Table 2. Published articles on LPV for the management of mesh complications: summary of selected outcomes literature

\begin{tabular}{|c|c|c|c|c|c|c|c|c|c|c|}
\hline Study ${ }^{a}$ & $\begin{array}{l}\text { Reported } \\
\text { year }\end{array}$ & $\begin{array}{l}\text { Case } \\
\text { No. }\end{array}$ & $\begin{array}{c}\text { Initial } \\
\text { surgery (n) }\end{array}$ & $\begin{array}{c}\text { Port } \\
\text { placement }\end{array}$ & $\begin{array}{l}\text { Operative } \\
\text { time }^{\text {b) }} \\
(\min )\end{array}$ & $\begin{array}{l}\text { Involved } \\
\text { site }\end{array}$ & $\begin{array}{c}\text { Urethral } \\
\text { catheter } \\
\text { indwelling } \\
\text { (day) }\end{array}$ & $\begin{array}{l}\text { Follow- } \\
\text { up }^{\text {b) }} \\
(\mathrm{mo})\end{array}$ & Recurrence & $\begin{array}{c}\text { Symptom } \\
\text { recovery } \\
\text { (day) }\end{array}$ \\
\hline Al-Badr [31] & 2005 & 3 & TVT & $\begin{array}{l}\text { Single with } \\
\text { cystoscope }\end{array}$ & N/A & Lateral wall & 3.0 & 1.5 & No & 3 \\
\hline Ingber [32] & 2009 & 2 & N/A & $\begin{array}{l}\text { Single } \\
\text { (Triport) }\end{array}$ & 113 & $\begin{array}{l}\text { Bladder neck, } \\
\text { dome }\end{array}$ & 7.0 & 7.0 & No & N/A \\
\hline Bekker [80] & 2010 & 1 & Prolift & $\begin{array}{l}3 \text { With } \\
\text { cystoscope }\end{array}$ & 31 & Lateral wall & 14.0 & 1.5 & No & N/A \\
\hline Yoshizawa [81] & 2011 & 2 & TOT & 3 & 146 & Lateral wall & 7.0 & 18.0 & No & N/A \\
\hline $\operatorname{Kim}[33]$ & 2012 & 3 & TOT & 3 & N/A & $\begin{array}{l}\text { Bladder neck, } \\
\text { anterior wall }\end{array}$ & 3.6 & 6.7 & No & $3-7^{c)}$ \\
\hline Roslan [34] & 2013 & 9 & $\begin{array}{l}\text { TVT (2) } \\
\text { Gynemesh (2) } \\
\text { TOT (1) } \\
\text { Prolift (1) } \\
\text { Etc (3) }\end{array}$ & $\begin{array}{l}\text { Single } \\
\text { (Triport) }\end{array}$ & 59 & $\begin{array}{l}\text { Bladder neck, } \\
\text { anterior wall }\end{array}$ & 5.9 & 18.8 & No & N/A \\
\hline
\end{tabular}

LPV, laparoscopic approach for intravesical surgery using pneumovesicum; TVT, tension-free vaginal tape; N/A, not applicable; TOT, transobturator tape.

${ }^{a)}$ First author [reference number]. ${ }^{\text {b) }}$ Mean. ${ }^{c}$ Range. 
muscle layers can prevent re-exposure of the erosion mesh $[12,33]$. However, Jo et al. [35] reported that mesh remnants were observed in 1 of 5 patients per group at 2-month followup using the transurethral approach.

\section{Management of VVF With LPV}

Surgical management of VVFs is most commonly performed vaginally, abdominally, or laparoscopically. Minimally invasive laparoscopic surgery is increasingly being performed, including laparoscopic VVF repair and robotic-assisted approach [36-40]. In their systematic review, Miklos et al. [41] reported that laparoscopic extravesical VVF repair has cure rates similar to the traditional transvesical approach. However, the laparoscopic or laparoscopic with robotic approach has distinct disadvantages, including increased learning curve, time, costs, and surgeons' experience [42]. Specifically, the long operative time (over 5-6 hours) was attributed to the difficulty in the identification of the fistulous tract, difficult dissection of the vesicovaginal space, and the need for defect suturing [43].

To overcome these limitations, a direct approach to the fistula tract using LPV has been attempted. Recently, Nerli and Reddy [44] first described that VVF repair with LPV technique is feasible and safe, and results in lower morbidity and quicker recovery time. Port placement and the method of creating the pneumovesical space are similar to the transvesicoscopic ureteral reimplantation technique. They presented the advantages of the current technique, including injury prevention to other intraperitoneal organs, need for peritoneal drain, and prolonged ileus. Above all, the current approach led the surgeon directly over the fistula, resulting in easy dissection of the bladder from the vagina [41]. However, this technique is unable to interpose healthy tissues such as the omentum and the tissue between the bladder and the vagina. Unfortunately, the man- agement of outcomes with this approach has not been reported. Although this procedure has the potential to be a good treatment option in patients with VVF, more studies are needed to assess its safety and efficacy.

\section{Removal of Bladder Stone or Foreign Body With LPV}

Open cystolithotomy is the most commonly used treatment modality for the removal of large bladder stones. In recent years, cystolithotripsy using Holmium laser has been widely used and its application range is gradually increasing. LPV can be used for patients with large bladder stones or multiple bladder stones. Hwang et al. [45] first reported bladder stones of 3 $\mathrm{cm}$ or more via laparoscopic entrapment sac using PV. Our center has also reported the utility of pneumovesical cystolithotripsy using a T-LESS for multiple small bladder stones [46]. They demonstrated that large bladder stone removal using PV is better than conventional cystolitholapaxy, and it reduces bladder damage except during port insertion, reduces the risk for urethral stricture, and has short operation time [45,47,48]. The open extraperitoneal approach or the transurethral approach using Holmium laser is known to be effective in managing large bladder stones [49]. Thus, LPV for bladder stones is restricted in special cases.

However, LPV can be a useful option in removing foreign bodies which are difficult to remove using the transurethral approach (e.g., long wire). Reddy et al. [50] reported that the LPV technique was also applied for removal of foreign bodies from the bladder. Through a single $10-\mathrm{mm}$ port insufflated with 12 mmHg of $\mathrm{CO}_{2}$, they crushed Blu Tack, a puttylike substance, and then removed it from the bladder of a 14-year-old boy [50]. The transurethral approach has limitations in the removal of linear foreign bodies due to sexual curiosity. In particular, the LPV approach has many advantages. As a result, scissors are

Table 3. Published case reports on LPV for the management of foreign bodies in the bladder

\begin{tabular}{|c|c|c|c|c|c|c|c|c|}
\hline Study $y^{a)}$ & Reported year & Country & Material & $\begin{array}{l}\text { Length } \\
(\mathrm{cm})\end{array}$ & Anesthesia & No. of port & $\begin{array}{l}\text { Operative time } \\
\text { (min) }\end{array}$ & $\begin{array}{l}\text { Hospital day } \\
\text { (day) }\end{array}$ \\
\hline Reddy [50] & 2004 & United Kingdom & Organic rubber & N/A & General & Single & N/A & 2 \\
\hline Pandey [82] & 2012 & India & Foley catheter & N/A & Spinal & Single & N/A & N/A \\
\hline Ko [51] & 2010 & Korea & Electric wire & 149 & General & Single & 21 & 1 \\
\hline Przudzik [12] & 2015 & Poland & Metallic cable & N/A & General & Single & 25 & 1 \\
\hline Jin [83] & 2016 & China & Intrauterine device & N/A & General & Two & N/A & 7 \\
\hline
\end{tabular}

LPV, laparoscopic approach for intravesical surgery using pneumovesicum; N/A, not applicable.

${ }^{a)}$ First author [reference number]. 
used for materials that are difficult to cut with a laser (Table 3). Przudzik et al. [12] and Ko et al. [51] described the advantage of using laparoscopic scissors with PV in the removal of a long cable in the bladder. The foreign body removal method using PV can be very useful in special cases where there is a risk of damaging the urethra or other injuries when pulling out via the transurethral approach. In addition, it offers short hospital stay and is less invasive [51].

\section{Management of BPH With LPV}

Mariano et al. [52] first presented the laparoscopic approach for the treatment of patients with large prostatic adenomas in 2002. Since then, many clinical studies have assessed laparoscopic simple prostatectomy. In a meta-analysis, Lucca et al. [53] reported that minimally invasive simple prostatectomy (conventional laparoscopic or robot-assisted approach) provides similar improvements in the maximum flow rate (Qmax) and International Prostate Symptom Score (IPSS) as open simple prostatectomy, and has distinct advantages including blood loss (de- crease $187 \mathrm{~mL}$ ), duration of catheter use (decrease 1.3 day), and hospital stay (decrease 1.6 day).

Desai et al. [54] first reported using the single-port laparoscopic transvesical enucleation of the prostate (STEP) technique using PV in 2008. In addition, they also observed that an entire adenoma can be effectively enucleated in a case series using the STEP technique, and found that it is suitable for patients with a large median lobe or coexisting bladder calculi [55]. Simple prostatectomy via the transvesical approach has some potential advantages over the transperitoneal laparoscopic approach. There is no need for peritoneal violation when using the transvesical approach, but it provides effective tamponade of the venous channels and excellent exposure of the prostatic fossa for additional hemostatic maneuvers if required and for confirming the adequacy of adenoma enucleation [55-58]. In particular, Wang et al. [57] demonstrated that the STEP technique improved the associated parameters, such as Qmax $(27.7 \mathrm{~mL} / \mathrm{sec})$, total IPSS (-18.2), and quality-of-life scores (-3.56) in a case series and literature review. However, they included STEP data

Table 4A. Single-port laparoscopic transvesical enucleation of the prostate using pneumovesicum: summary of selected outcomes literature

\begin{tabular}{|c|c|c|c|c|c|c|c|c|c|c|c|c|c|}
\hline Study ${ }^{a)}$ & $\begin{array}{l}\text { Reported } \\
\text { year }\end{array}$ & $\begin{array}{c}\text { No. of } \\
\text { patients }\end{array}$ & Country & $\begin{array}{c}\text { Prostate } \\
\text { volume }^{\text {b) }}\end{array}$ & $\begin{array}{c}\text { Excised } \\
\text { prostate } \\
(\%)\end{array}$ & $\begin{array}{l}\text { Age }^{c)} \\
(y r)\end{array}$ & $\begin{array}{c}\text { Operative } \\
\text { time }^{c} \\
(\mathrm{~min})\end{array}$ & $\begin{array}{c}\text { Hospital } \\
\text { dayc) }^{\text {c) }} \\
\text { (day) }\end{array}$ & $\begin{array}{l}\text { Catheter- } \\
\text { ization } \\
\text { time }^{\text {c) }} \text { (day) }\end{array}$ & $\begin{array}{l}\text { Blood } \\
\text { loss }^{\text {c) }} \\
(\mathrm{mL})\end{array}$ & $\begin{array}{l}\text { Compli- } \\
\text { cation }\end{array}$ & $\begin{array}{c}\text { Open } \\
\text { conver- } \\
\text { sion }\end{array}$ & $\begin{array}{c}\text { Transfu- } \\
\text { sion }\end{array}$ \\
\hline Desai [54] & 2008 & 3 & USA & 124 & 86.6 & 76.7 & 200.0 & 1.7 & 4.0 & 500.0 & $1 / 3$ & $0 / 3$ & $1 / 3$ \\
\hline Desai [55] & 2010 & 34 & USA & $102 \pm 51$ & 66.3 & 69.0 & 116.0 & 3.0 & 6.0 & 460.0 & $8 / 34$ & $4 / 34$ & $2 / 34$ \\
\hline Oh [56] & 2011 & 32 & Korea & $73 \pm 20$ & 76.7 & 70.2 & 109.4 & 3.0 & 5.3 & 177.0 & $0 / 32$ & $0 / 32$ & $2 / 32$ \\
\hline Lee [58] & 2012 & 7 & Korea & $101 \pm 16$ & 53.7 & N/A & 189.3 & 3.1 & 5.3 & 600.0 & $0 / 7$ & $1 / 8$ & $2 / 7$ \\
\hline Wang [57] & 2012 & 8 & China & $83.8 \pm 19$ & 64.6 & 71.9 & 160.9 & 7.0 & 8.6 & 418.8 & $3 / 8$ & $1 / 9$ & $1 / 8$ \\
\hline
\end{tabular}

N/A, not applicable.

${ }^{a}$ First author [reference number]. ${ }^{\text {b) }}$ Mean \pm standard deviation. ${ }^{\text {c) }}$ Mean.

Table 4B. Single-port laparoscopic transvesical enucleation of the prostate using pneumovesicum: outcomes of IPSS and urodynamic parameter

\begin{tabular}{|c|c|c|c|c|c|c|c|c|}
\hline Study $y^{a)}$ & Preop total IPSS & Preop QoL & $\begin{array}{l}\text { Preop Qmax } \\
(\mathrm{mL} / \mathrm{sec})\end{array}$ & $\begin{array}{l}\text { Pre-PVR } \\
(\mathrm{mL})\end{array}$ & Postop IPSS & Postop QoL & $\begin{array}{l}\text { Postop Qmax } \\
\quad(\mathrm{mL} / \mathrm{sec})\end{array}$ & $\begin{array}{c}\text { Post-PVR } \\
(\mathrm{mL})\end{array}$ \\
\hline Desai [54] & N/A & N/A & N/A & N/A & N/A & N/A & N/A & N/A \\
\hline Desai [55] & $19 \pm 5$ & N/A & $7.8 \pm 3.8$ & N/A & $3 \pm 1.7$ & N/A & $44 \pm 18$ & N/A \\
\hline Lee $[58]$ & $23.57 \pm 2.15$ & N/A & $6.7 \pm 2.3$ & $170.3 \pm 101.3$ & $11.43 \pm 2.44$ & N/A & $17.1 \pm 3.4$ & $34.1 \pm 21.1$ \\
\hline $\mathrm{Oh}[56]$ & $27.1 \pm 7.3$ & $4.7 \pm 0.7$ & $5.8 \pm 1.6$ & N/A & $4.0 \pm 1.1$ & $1.1 \pm 0.4$ & $36.2 \pm 6.6$ & $66.3 \pm 25.0$ \\
\hline Wang [57] & 25.6 & 4.6 & 9.8 & N/A & $4.1 \pm 1.4$ & $1.4 \pm 1.2$ & $22.7 \pm 4.6$ & $36.1 \pm 40.0$ \\
\hline
\end{tabular}

Values are presented as mean \pm standard deviation.

IPSS, International prostate symptom score; Preop, preoperative; Postop, postoperative; QoL, quality of life; Qmax, maximum urinary flow rate; PVR, postvoid residual urine volume; SD, standard deviation; N/A, Not applicable.

${ }^{\text {a) }}$ First author [reference number]. 
without using PV. The surgical outcomes of STEP with PV are listed in Table 4A, B.

The current approach has several limitations. Surgeons without experience in laparo-endoscopic single-site surgeries or conventional laparoscopy may have a steep learning curve [58]. In addition, Desai et al. [55] reported that the dissection toward the apical adenoma is more difficult than in the conventional laparoscopic approach. The current approach is less suitable for small glands, morbidly obese patients, and patients with a long and predominantly infravesical prostates [55].

Holmium laser enucleation has recently emerged as an effective treatment because it guarantees similar and durable functional results as well as a significantly reduced transfusion rate, a shorter period of catheterization, and a shorter hospital stay $[59,60]$. In addition, bipolar transurethral resection of the prostate (TURP) has been proposed to treat large adenomas with similar efficacy and lower morbidity, compared with open prostatectomy [61]. Although STEP has better cosmesis than open surgery or conventional laparoscopic surgery, it may require a suprapubic catheter and result in an external wound than did TURP or Holmium laser enucleation. Therefore, STEP does not seem to be more advantageous than other procedures for most patients with $\mathrm{BPH}$ [58].

\section{Oncology}

\section{Prostate cancer}

Laparoscopic with or without robot-assisted radical prostatectomy (RP) has been increasingly used for the surgical treatment of patients with localized prostate cancer, with results comparable to open retropubic RP $[62,63]$. As part of an attempt to performed more minimally invasive surgery, Desai et al. [64] tried the transvesical approach robot-assisted laparoscopic RP using $\mathrm{PV}$ in 2 fresh cadavers. In their initial report, the total operative time was 3 and 4.2 hours, respectively, and the time to obtain transvesical access was approximately 30 minutes. Since then, Gao et al. [65] first presented their initial clinical experience with single-port transvesical laparoscopic RP using PV in 16 consecutive patients with localized prostate cancer. In their case series, the mean operative time was 105 minutes, and mean blood loss $130 \mathrm{~mL}$. Overall, $81.2 \%$ of the patients showed continence when the catheter was removed, and $75 \%$ of the patients achieved potency 12 months postoperatively.

The current technique has some advantages, including not needing to mobilize the bladder or dissecting the perivesical space [65]. In addition, PV minimized the effects of mechanical ventilation, potentially enabling the procedure to be performed under regional (spinal and epidural) anesthesia [64]. However, lymph node dissection and bladder reconstruction cannot be done using that approach $[64,65]$. Furthermore, it is likely to require considerable training and experience because of limited operating space, considerable clashing of instruments, limited precision of tissue handling and retraction.

Given these limitations, these methods are not selected by many clinicians. For these methods to be widely performed in patients with prostate cancer, the development of techniques, to avoid instrument clashing, and surgical methods, to overcome the long learning curve, is needed. In addition, longer survival and functional data, and randomized prospective studies in a larger cohort of patients are necessary to determine the appropriate role of the current approach [65].

\section{Upper tract urothelial cell carcinoma}

Radical nephroureterectomy (RNU) with excision of the bladder cuff is recognized as the standard treatment for patients with upper tract urothelial cell carcinoma [66]. However, controversy still exists about the best method for managing the distal ureter and bladder cuff. Many techniques for ureter and bladder cuff resection have been described, including open excision, endoscopic excision, and laparoscopic stapling [67]. Among these techniques, the endoscopic approach was associated with higher intravesical recurrence (5-year intravesical recurrence-free survival rate of $42 \%$ ) in a large multicenter study [68]. In addition, Matin and Gill [69] reported that positive margins were more frequently associated with the laparoscopic stapling approach than with either the transvesical or open techniques in a retrospective study. While the absolute intravesical recurrence rate was different between the transvesical and extravesical approaches, they found no difference in any of the outcomes between these approaches [68].

Cheng et al. [70] first described using a transvesical PV method for managing the distal ureter during laparoscopic RNU. They observed that the approach minimized tumor seeding with early closure of the ureteric orifice during distal ureteric dissection and used a PV instead of fluid irrigation. Since then, bladder cuffing with PV has been performed in various institutions; the results are reported in Table 5.

After establishing the PV, three ports or laparoendoscopic single ports are placed into the bladder transversely above the pubic bone. The distal ureter, bladder cuff, and intramural ureter are then completely dissected using electrocautery [71]. As 
Table 5. Published case report on the LPV for the management of distal ureter and bladder cuffing in nephroureterectomy

\begin{tabular}{|c|c|c|c|c|c|c|c|c|c|c|c|}
\hline Study ${ }^{a)}$ & $\begin{array}{l}\text { Reported } \\
\text { year }\end{array}$ & $\begin{array}{c}\text { No. of } \\
\text { patients }\end{array}$ & $\begin{array}{l}\text { RNU } \\
\text { surgery } \\
\text { type (n) }\end{array}$ & $\begin{array}{l}\text { Operating } \\
\text { time for } \\
\left.\text { distal ureter }{ }^{\mathrm{b}}\right) \\
\quad(\mathrm{min})\end{array}$ & $\begin{array}{l}\text { Extravasation } \\
\text { on } \\
\text { cystography }\end{array}$ & $\begin{array}{l}\text { Positive } \\
\text { surgical } \\
\text { margin }\end{array}$ & $\begin{array}{l}\text { Tumor } \\
\text { site (n) }\end{array}$ & $\begin{array}{l}\text { T stage } \\
\text { (n) }\end{array}$ & $\begin{array}{l}\text { Follow } \\
\text {-up } \\
(\mathrm{mo})^{\mathrm{c})}\end{array}$ & $\begin{array}{l}\text { Intravesical } \\
\text { recurrence }\end{array}$ & $\begin{array}{l}\text { Systemic } \\
\text { recurrence }\end{array}$ \\
\hline Cheng [70] & 2008 & 1 & LNU (1) & N/A & N/A & $\mathrm{N} / \mathrm{A}$ & $\mathrm{N} / \mathrm{A}$ & $\mathrm{N} / \mathrm{A}$ & N/A & N/A & N/A \\
\hline $\begin{array}{l}\text { Giannakopoulos } \\
\text { [84] }\end{array}$ & 2012 & 10 & $\begin{array}{l}\text { ONU (2) } \\
\text { LNU (8) }\end{array}$ & 82.5 & $2 / 10$ & $0 / 10$ & $\begin{array}{l}\text { Ureter (2) } \\
\text { Renal } \\
\text { pelvis (8) }\end{array}$ & $\begin{array}{l}\text { Ta-1 (7) } \\
\text { T2 (2) } \\
\text { T3 (1) }\end{array}$ & $\begin{array}{c}31 \\
(12-55)\end{array}$ & $3 / 10$ & $2 / 10$ \\
\hline Zou [73] & 2010 & 6 & LNU (6) & 26.5 & $0 / 6$ & $0 / 6$ & $\begin{array}{l}\text { Ureter (2) } \\
\text { Renal } \\
\text { pelvis (4) }\end{array}$ & $\begin{array}{l}\text { Ta-1 (2) } \\
\text { T2 (3) } \\
\text { T3 (1) }\end{array}$ & $\begin{array}{c}18 \\
(5-28)\end{array}$ & $0 / 6$ & $0 / 6$ \\
\hline Roslan [13] & 2014 & 5 & LNU (5) & 59.0 & $0 / 5$ & $0 / 5$ & $\begin{array}{l}\text { Ureter (0) } \\
\text { Renal } \\
\text { pelvis (5) }\end{array}$ & $\begin{array}{l}\text { Ta-1 (2) } \\
\text { T2 (1) } \\
\text { T3 (2) }\end{array}$ & $\begin{array}{c}6 \\
(4-10)\end{array}$ & N/A & N/A \\
\hline Guzzo [85] & 2008 & 1 & LNU (1) & N/A & N/A & N/A & N/A & N/A & N/A & N/A & N/A \\
\hline Mak [71] & 2011 & 10 & LNU (10) & N/A & $0 / 10$ & N/A & $\begin{array}{l}\text { Ureter (3) } \\
\text { Renal } \\
\text { pelvis (7) }\end{array}$ & $\begin{array}{l}\text { Ta-1 (3) } \\
\text { T2 (2) } \\
\text { T3 (5) }\end{array}$ & $\begin{array}{c}46 \\
(22-67)\end{array}$ & $4 / 10$ & $1 / 10$ \\
\hline $\begin{array}{l}\text { Nunez } \\
\text { Bragayrac [86] }\end{array}$ & 2014 & 5 & LNU (5) & 35.0 & $0 / 5$ & $0 / 5$ & $\begin{array}{l}\text { Ureter (0) } \\
\text { Renal } \\
\text { pelvis (5) }\end{array}$ & N/A & $\begin{array}{c}16.2 \\
(1-38)\end{array}$ & N/A & $1 / 5$ \\
\hline
\end{tabular}

LPV, laparoscopic approach for intravesical surgery using pneumovesicum; RNU, radical nephroureterectomy; LNU, laparoscopic nephroureterectomy; ONU, open nephroureterectomy; N/A, not applicable.

${ }^{a)}$ First author [reference number]. ${ }^{\text {b) }}$ Mean. ${ }^{c}$ Median (range).

soon as the distal ureter is dissected, an ENDOLOOP knot is used to ligate the ureter to avoid tumor spillage and aid in the identification of the ureter during final laparoscopic extraction. The bladder defect at the site of the ureteral dissection is closed in 2 layers with a 2-0 (or 1-0) absorbable polyglactin suture.

This method has several theoretical advantages, including en bloc removal of the entire specimen, excellent visualization of the bladder and minimization of the potential for tumor seeding with early closure of the distal ureteral orifice, and the use of PV instead of fluid irrigation [72]. In addition, this method does not require large transvesical incision, so it improves recovery times, and minimizes bladder spasms and hematuria. However, only small case series with limited number of patients with upper tract urothelial cancers were conducted, and the follow-up duration was short. In addition, the theoretical risk for tumor seeding during port insertion is present. Fortunately, no studies have shown pelvic, peritoneal, or port site recurrence after the current surgery. Finally, this surgical procedure should be avoided if patients showed urothelial cancer in the intramural ureter or have history of overactive bladder or pelvic irradiation [73].

\section{Bladder Diverticulectomy}

Bladder diverticulum can be found immediately under transvesical approach. This procedure has been performed by some surgeons. Pansadoro et al. [74] first described transvesical laparoscopic bladder diverticulectomy using PV via a 3-port technique. Roslan et al. [14,75] was the first to publish a case series for T-LESS for bladder diverticulectomy. Recently, Magdy et al. [76] demonstrated a natural orifice transluminal endoscopic surgery for bladder diverticulectomy.

Although port placement may different for each surgeon, the surgical method does not. After the PV is established, circumferential incision of the mouth of the diverticulum was made using monopolar electrocautery scissors. The diverticular mucosa is then grasped and separated from the detrusor muscle attachments. Bladder defects were closed using barbed suture in one layer.

Roslan et al. [75] presented that the current approach provides the same benefits as the laparoscopic approach in terms of blood loss, postoperative analgesic requirements, and hospital stay, but the operative time (mean operative time, $122 \mathrm{~min}$ utes) is comparable to that achieved during open or endoscopic 
surgery. However, the current method may be difficult to apply in domal and anterior wall diverticula, which are not common sites [76]. In addition, relatively small operative field and clashing of the instruments can be potent limitations of this approach [14].

\section{DISCUSSION}

LPV has been applied in various urology fields. It is expected to be used in other fields in the future because of its excellent visibility, less morbidity, and improved cosmesis. However, the difficulty of the procedure and relatively long learning curve needs to be overcome. In addition, the lack of long-term follow-up data makes surgeons hesitant to choose the current approach. However, with the expected development of instruments including those for robotic surgery, the limitations of the current approach are likely to be overcome. Additional studies are needed to better define the ideal surgical approach and present evidence of usable treatment options for various urological diseases.

\section{AUTHOR CONTRIBUTION STATEMENT}

- Full access to all the data in the study and takes responsibility for the integrity of the data and the accuracy of the data analysis: Bum Sik Tae, Jae Hyun Bae

- Study concept and design: Bum Sik Tae, Jae Hyun Bae

- Acquisition of data: Bum Sik Tae, Hoon Choi

- Analysis and interpretation of data: Bum Sik Tae, Jae Hyun Bae

- Drafting of the manuscript: Bum Sik Tae, Jae Hyun Bae

- Critical revision of the manuscript for important intellectual content: Hoon Choi, Jae Young Park, Jae Hyun Bae

- Statistical analysis: Bum Sik Tae

- Administrative, technical, or material support: Jae Hyun Bae

- Study supervision: Jae Hyun Bae

\section{REFERENCES}

1. Wear JB. Cystoscopy with carbon dioxide irrigation. J Urol 1966; 96:828.

2. Yeung CK, Sihoe JD, Borzi PA. Endoscopic cross-trigonal ureteral reimplantation under carbon dioxide bladder insufflation: a novel technique. J Endourol 2005;19:295-9.

3. Chung PH, Tang DY, Wong KK, Yip PK, Tam PK. Comparing open and pneumovesical approach for ureteric reimplantation in pediatric patients; a preliminary review. J Pediatr Surg 2008;43:
2246-9.

4. Choi H, Park JY, Bae JH. Initial experiences of laparoscopic intravesical detrusorraphy using the Politano-Leadbetter technique. J Pediatr Urol 2016;12:110.e1-7.

5. Marte A, Sabatino MD, Borrelli M, Nino F, Prezioso M, Pintozzi L, et al. Pneumovesicoscopic correction of primary vesicoureteral reflux (VUR) in children. Our experience. Eur J Pediatr Surg 2010; 20:366-70.

6. Valla JS, Steyaert H, Griffin SJ, Lauron J, Fragoso AC, Arnaud P, et al. Transvesicoscopic Cohen ureteric reimplantation for vesicoureteral reflux in children: a single-centre 5-year experience. J Pediatr Urol 2009;5:466-71.

7. Soh S, Kobori Y, Shin T, Suzuki K, Iwahata T, Sadaoka Y, et al. Transvesicoscopic ureteral reimplantation: Politano-Leadbetter versus Cohen technique. Int J Urol 2015;22:394-9.

8. Xiang B, Liu JX, Sung HB, Yan B, Cheng W. The effect of $\mathrm{CO}_{2}$ pneumovesicum on upper urinary tract. J Pediatr Surg 2010;45: 1863-7.

9. Steyaert H, Valla JS. Minimally invasive urologic surgery in children: an overview of what can be done. Eur J Pediatr Surg 2005;15: 307-13.

10. Hong CH, Kim JH, Jung HJ, Im YJ, Han SW. Single-surgeon experience with transvesicoscopic ureteral reimplantation in children with vesicoureteral reflux. Urology 2011;77:1465-9.

11. Kutikov A, Guzzo TJ, Canter DJ, Casale P. Initial experience with laparoscopic transvesical ureteral reimplantation at the Children's Hospital of Philadelphia. J Urol 2006;176:2222-5; discussion 22256.

12. Przudzik M, Borowik M, Łesiów R, Purpurowicz Z, Roslan M. Transvesical laparoendoscopic single-site surgery (T-LESS) to remove an unusual foreign body from the bladder. Cent European J Urol 2016;69:312.

13. Roslan M, Markuszewski M, Kłącz J, Sieczkowski M, Połom W, Piaskowski W, et al. Laparoscopic nephroureterectomy with transvesical single-port distal ureter and bladder cuff dissection: points of technique and initial surgical outcomes with five patients. Wideochir Inne Tech Maloinwazyjne 2014;9:267-72.

14. Roslan M, Markuszewski M, Kłącz J, Krajka K. Suprapubic transvesical laparoendoscopic single-port bladder diverticulectomy: points of technique with medium-term surgical outcomes. J Endourol 2013;27:688-92.

15. Ansari MS, Yadav P, Arora S, Singh P, Sekhon V. Bilateral transvesicoscopic cross-trigonal ureteric reimplantation in children: surgical subtleties and a prospective summary. Urology 2017;101:67-72.

16. Jayanthi V, Patel A. Vesicoscopic ureteral reimplantation: a mini- 
mally invasive technique for the definitive repair of vesicoureteral reflux. Adv Urol 2008:973616.

17. Kilincaslan H, Gundogdu G, Terzi EH, Ozturk H, Firat T, Tosun M. Carbon dioxide insufflation causes upper urinary tract injury in the early period of an experimental vesicoureteral reflux model. Pediatr Surg Int 2013;29:1311-20.

18. Lakshmanan Y, Fung LC. Laparoscopic extravesicular ureteral reimplantation for vesicoureteral reflux: recent technical advances. J Endourol 2000;14:589-93; discussion 593-4.

19. Gill IS, Ponsky LE, Desai M, Kay R, Ross JH. Laparoscopic crosstrigonal Cohen ureteroneocystostomy: novel technique. J Urol 2001;166:1811-4.

20. Tekgül S, Riedmiller H, Hoebeke P, Kočvara R, Nijman RJ, Radmayr $\mathrm{C}$, et al. EAU guidelines on vesicoureteral reflux in children. Eur Urol 2012;62:534-42.

21. Emir H, Mammadov E, Elicevik M, Buyukunal C, Soylet Y. Transvesicoscopic cross-trigonal ureteroneocystostomy in children: a single-center experience. J Pediatr Urol 2012;8:83-6.

22. Steffens J, Stark E, Haben B, Treiyer A. Surgical atlas PolitanoLeadbetter ureteric reimplantation. BJU Int 2006;98:695-712.

23. Choi H, Bae JH. Report of new technique: transvesicoscopic Politano-Leadbetter ureteral reimplantation. J Laparoendoscopic Adv Sur Tech B 2013;23. https://doi.org/10.1089/vor.2012.0133.

24. Canon SJ, Jayanthi VR, Patel AS. Vesicoscopic cross-trigonal ureteral reimplantation: a minimally invasive option for repair of vesicoureteral reflux. J Urol 2007;178:269-73; discussion 273.

25. Liu X, Liu JH, Zhang DY, Hua Y, Lin T, Wei GH, et al. Retrospective study to determine the short-term outcomes of a modified pneumovesical Glenn-Anderson procedure for treating primary obstructing megaureter. J Pediatr Urol 2015;11:266.e1-6.

26. Kim SW, Lim NL, Lee YS, Han SW, Im YJ. Laparoscopic intravesical detrusorrhaphy with ureteral plication for megaureter: a novel technique. Urology 2015;86:187-91.

27. Deffieux X, Bonnet K, Chevalier N, Gervaise A, Frydman R, Fernandez $\mathrm{H}$. Urinary complications in sub-urethral sling procedures. J Gynecol Obstet Biol Reprod (Paris) 2005;34:745-56.

28. Hammad FT, Kennedy-Smith A, Robinson RG. Erosions and urinary retention following polypropylene synthetic sling: Australasian survey. Eur Urol 2005;47:641-6; discussion 646-7.

29. Deng DY, Rutman M, Raz S, Rodriguez LV. Presentation and management of major complications of midurethral slings: Are complications under-reported? Neurourol Urodyn 2007;26:46-52.

30. Giri SK, Drumm J, Flood HD. Endoscopic holmium laser excision of intravesical tension-free vaginal tape and polypropylene suture after anti-incontinence procedures. J Urol 2005;174(4 Pt 1):1306-7.
31. Al-Badr A, Fouda K. Suprapubic-assisted cystoscopic excision of intravesical tension-free vaginal tape. J Minim Invasive Gynecol 2005;12:370-1.

32. Ingber MS, Stein RJ, Rackley RR, Firoozi F, Irwin BH, Kaouk JH, et al. Single-port transvesical excision of foreign body in the bladder. Urology 2009;74:1347-50.

33. Kim JH, Doo SW, Yang WJ, Song YS. Laparoscopic transvesical excision and reconstruction in the management of mid-urethral tape mesh erosion and stones around the bladder neck: initial experiences. BJU Int 2012;110(11 Pt C):E1009-13.

34. Roslan M, Markuszewski MM. Transvesical laparoendoscopic single site surgery to remove surgical materials penetrating the bladder: initial clinical experience in 9 female patients. J Urol 2013; 190:909-15.

35. Jo DJ, Lee YS, Oh TH, Ryu DS, Kwak KW. Outcomes of transurethral removal of intravesical or intraurethral mesh following midurethral sling surgery. Korean J Urol 2011;52:829-34.

36. Ghoniem GM, Warda HA. The management of genitourinary fistula in the third millennium. Arab J Urol 2014;12:97-105.

37. Ou CS, Huang UC, Tsuang M, Rowbotham R. Laparoscopic repair of vesicovaginal fistula. J Laparoendosc Adv Surg Tech A 2004; 14:17-21.

38. Chibber PJ, Shah HN, Jain P. Laparoscopic O'Conor's repair for vesico-vaginal and vesico-uterine fistulae. BJU Int 2005;96:183-6.

39. Bragayrac LA, Azhar RA, Fernandez G, Cabrera M, Saenz E, Machuca V, et al. Robotic repair of vesicovaginal fistulae with the transperitoneal-transvaginal approach: a case series. Int Braz J Urol 2014;40:810-5.

40. Hemal AK, Kolla SB, Wadhwa P. Robotic reconstruction for recurrent supratrigonal vesicovaginal fistulas. J Urol 2008;180:981-5.

41. Miklos JR, Moore RD, Chinthakanan O. Laparoscopic and roboticassisted vesicovaginal fistula repair: a systematic review of the literature. J Minim Invasive Gynecol 2015;22:727-36.

42. Bodner-Adler B, Hanzal E, Pablik E, Koelbl H, Bodner K. Management of vesicovaginal fistulas (VVFs) in women following benign gynaecologic surgery: a systematic review and meta-analysis. PLoS One 2017;12:e0171554.

43. Otsuka RA, Amaro JL, Tanaka MT, Epacagnan E, Mendes JB Jr, Kawano PR, et al. Laparoscopic repair of vesicovaginal fistula. J Endourol 2008;22:525-7.

44. Nerli RB, Reddy M. Transvesicoscopic repair of vesicovaginal fistula. Diagn Ther Endosc 2010;2010:760348.

45. Hwang JS, Son JH, Jang SH, Lee JW, Cho DS, Lim CH, et al. The initial experience of pneumovesicoscopic bladder stone removal using a laparoscopic entrapment sac. Urology 2014;84:1234-9. 
46. Choi H, Bae JH. Laparoscopic single port cystolithotomy using pneumovesicum. Int Braz J Urol 2016;42:1047-8.

47. Rana A, Rashwan HM, West Of Stow J, Ng PE, Chisholm GD. Air insufflation versus water irrigation during flexible cystoscopy: a prospective randomized study. Br J Urol 1994;74:311-4.

48. Ciudin A, Diaconu MG, Gosalbez D, Peri L, Garcia-Cruz E, Franco A, et al. Air cystoscopy is superior to water cystoscopy for the diagnosis of active hematuria. J Urol 2013;190:2097-101.

49. Gangkak G, Yadav SS, Tomar V, Vyas N, Jain D. Pneumatic cystolithotripsy versus holmium:yag laser cystolithotripsy in the treatment of pediatric bladder stones: a prospective randomized study. Pediatr Surg Int 2016;32:609-14.

50. Reddy BS, Daniel RD. A novel laparoscopic technique for removal of foreign bodies from the urinary bladder using carbon dioxide insufflation. Surg Laparosc Endosc Percutan Tech 2004;14:238-9.

51. Ko YH, Kang SG, Kang SH, Park HS, Lee JG, Kim JJ, et al. Removal of long, complex foreign bodies from bladder using single laparoscopic port under pneumovesicum. J Laparoendosc Adv Surg Tech A 2010;20:639-42.

52. Mariano MB, Graziottin TM, Tefilli MV. Laparoscopic prostatectomy with vascular control for benign prostatic hyperplasia. J Urol 2002;167:2528-9.

53. Lucca I, Shariat SF, Hofbauer SL, Klatte T. Outcomes of minimally invasive simple prostatectomy for benign prostatic hyperplasia: a systematic review and meta-analysis. World J Urol 2015;33:563-70.

54. Desai MM, Aron M, Canes D, Fareed K, Carmona O, Haber GP, et al. Single-port transvesical simple prostatectomy: initial clinical report. Urology 2008;72:960-5.

55. Desai MM, Fareed K, Berger AK, Astigueta JC, Irwin BH, Aron M, et al. Single-port transvesical enucleation of the prostate: a clinical report of 34 cases. BJU Int 2010;105:1296-300.

56. Oh JJ, Park DS. Novel surgical technique for obstructive benign prostatic hyperplasia: finger-assisted, single-port transvesical enucleation of the prostate. J Endourol 2011;25:459-64.

57. Wang L, Liu B, Yang Q, Wu Z, Yang B, Xu Z, et al. Preperitoneal single-port transvesical enucleation of the prostate (STEP) for large-volume BPH: one-year follow-up of Qmax, IPSS, and QoL. Urology 2012;80:323-8.

58. Lee JY, Han JH, Moon HS, Yoo TK, Choi HY, Lee SW. Single-port transvesical enucleation of the prostate for benign prostatic hyperplasia with severe intravesical prostatic protrusion. World J Urol 2012;30:511-7.

59. Kuntz RM, Lehrich K, Ahyai SA. Holmium laser enucleation of the prostate versus open prostatectomy for prostates greater than 100 grams: 5-year follow-up results of a randomised clinical trial. Eur
Urol 2008;53:160-6.

60. Bae J, Choo M, Park JH, Oh JK, Paick JS, Oh SJ. Holmium laser enucleation of prostate for benign prostatic hyperplasia: seoul national university hospital experience. Int Neurourol J 2011;15:2934.

61. Kwon JS, Lee JW, Lee SW, Choi HY, Moon HS. Comparison of effectiveness of monopolar and bipolar transurethral resection of the prostate and open prostatectomy in large benign prostatic hyperplasia. Korean J Urol 2011;52:269-73.

62. Touijer K, Eastham JA, Secin FP, Romero Otero J, Serio A, Stasi J, et al. Comprehensive prospective comparative analysis of outcomes between open and laparoscopic radical prostatectomy conducted in 2003 to 2005. J Urol 2008;179:1811-7; discussion 1817.

63. Badani KK, Kaul S, Menon M. Evolution of robotic radical prostatectomy: assessment after 2766 procedures. Cancer 2007;110:19518.

64. Desai MM, Aron M, Berger A, Canes D, Stein R, Haber GP, et al. Transvesical robotic radical prostatectomy. BJU Int 2008;102:16669.

65. Gao X, Pang J, Si-tu J, Luo Y, Zhang H, Li LY, et al. Single-port transvesical laparoscopic radical prostatectomy for organ-confined prostate cancer: technique and outcomes. BJU Int 2013;112:94452.

66. Margulis V, Shariat SF, Matin SF, Kamat AM, Zigeuner R, Kikuchi E, et al. Outcomes of radical nephroureterectomy: a series from the Upper Tract Urothelial Carcinoma Collaboration. Cancer 2009; 115:1224-33.

67. Macejko AM, Pazona JF, Loeb S, Kimm S, Nadler RB. Management of distal ureter in laparoscopic nephroureterectomy: a comprehensive review of techniques. Urology 2008;72:974-81.

68. Xylinas E, Rink M, Cha EK, Clozel T, Lee RK, Fajkovic H, et al. Impact of distal ureter management on oncologic outcomes following radical nephroureterectomy for upper tract urothelial carcinoma. Eur Urol 2014;65:210-7.

69. Matin SF, Gill IS. Recurrence and survival following laparoscopic radical nephroureterectomy with various forms of bladder cuff control. J Urol 2005;173:395-400.

70. Cheng CW, Ng CF, Mak SK, Chan SY, Wong YF, Chan CK, et al. Pneumovesicum method in en-Bloc laparoscopic nephroureterectomy with bladder cuff resection for upper-tract urothelial cancer. J Endourol 2007;21:359-63; discussion 362-3.

71. Mak SK, Ng CF, Chan ES, Yip SK, Cheng CW, Wong WS. Pneumovesicum approach to en-bloc laparoscopic nephroureterectomy with bladder cuff excision for upper tract urothelial cancer: midterm oncological results. J Endourol 2011;25:611-4. 
72. Phé V, Cussenot O, Bitker MO, Rouprêt M. Does the surgical technique for management of the distal ureter influence the outcome after nephroureterectomy? BJU Int 2011;108:130-8.

73. Zou X, Zhang G, Wang X, Yuan Y, Xiao R, Wu G, et al. A one-port pneumovesicum method in en bloc laparoscopic nephroureterectomy with bladder cuff resection is feasible and safe for upper tract transitional cell carcinoma. BJU Int 2011;108:1497-500.

74. Pansadoro V, Pansadoro A, Emiliozzi P. Laparoscopic transvesical diverticulectomy. BJU Int 2009;103:412-24.

75. Roslan M, Markuszewski MM, Kłącz J, Krajka K. Laparoendoscopic single-port transvesical diverticulectomy: preliminary clinical experience. J Endourol 2012;26:975-9.

76. Magdy A, Drerup M, Bauer S, Colleselli D, Hruby S, Mitterberger $\mathrm{M}$, et al. Natural orifice transluminal endoscopic surgery-assisted laparoscopic transvesical bladder diverticulectomy: feasibility study, points of technique, and case series with medium-term follow-up. J Endourol 2016;30:526-31.

77. Kawauchi A, Naitoh Y, Soh J, Hirahara N, Okihara K, Miki T. Transvesical laparoscopic cross-trigonal ureteral reimplantation for correction of vesicoureteral reflux: initial experience and comparisons between adult and pediatric cases. J Endourol 2009;23:1875-8.

78. Abraham MK, Viswanath N, Bindu S, Kedari P, Ramakrishnan P, Naaz A, et al. A simple and safe technique for trocar positioning in vesicoscopic ureteric reimplantation. Pediatr Surg Int 2011;27: 1223-6.

79. Chung MS, Han SW, Jung HJ, Im YJ, Han HH, Na JC, et al. Transvesicoscopic ureteral reimplantation in children with bilateral vesi- coureteral reflux: surgical technique and results. J Laparoendosc Adv Surg Tech A 2012;22:295-300.

80. Bekker MD, Bevers RF, Elzevier HW. Transurethral and suprapubic mesh resection after Prolift bladder perforation: a case report. Int Urogynecol J 2010;21:1301-3.

81. Yoshizawa T, Yamaguchi K, Obinata D, Sato K, Mochida J, Takahashi S. Laparoscopic transvesical removal of erosive mesh after transobturator tape procedure. Int J Urol 2011;18:861-3.

82. Pandey PK, Suruchi S, Kumar BM, Kumar SP, Pratap SJ. Pneumovesicoscopy: an effective technique for urinary bladder foreign body. Urol J 2014;10:1140-1.

83. Jin C, Fan Y, Zhang Q, Wang Y, Wu S, Jin J. Removal of foreign bodies embedded in the urinary bladder wall by a combination of laparoscopy and carbon dioxide cystoscopic assistance: Case report and literature review. Investig Clin Urol 2016;57:449-52.

84. Giannakopoulos S, Toufas G, Dimitriadis C, Giannopoulos S, Kalaitzis $\mathrm{C}$, Bantis A, et al. Laparoscopic transvesical resection of an en bloc bladder cuff and distal ureter during nephroureterectomy. ScientificWorldJournal 2012;2012:658096.

85. Guzzo TJ, Schaeffer EM, Allaf ME. Laparoscopic radical nephroureterectomy with en-bloc distal ureteral and bladder cuff excision using a single position pneumovesicum method. Urology 2008; 72:850-2.

86. Nunez Bragayrac LA, Machuca V, Saenz E, Cabrera M, de Andrade R, Sotelo RJ. Transvesical laparoendoscopic single-site management of distal ureter during laparoscopic radical nephroureterectomy. J Endourol 2014 Sep 11 [Epub]. https://doi.org/10.1089/end.2014.0071. 